\title{
Age Related Clinical Spectrum of Atopic Dermatitis: A Position Paper Virendra N Sehgal*
}

Department of Dermato-Venereology (Skin/VD) Center, Sehgal Nursing Home, Panchwati, Delhi-110 033, India

*Corresponding author: Sehgal VN, Department of Dermato-Venereology (Skin/VD) Center, Sehgal Nursing Home, Panchwati, Delhi-110 033, India, Tel: 011-27675363; Fax: 91-11-2767-0373; Mob: 98101-82241; E-mail: sehgalvn@yahoo.co.in; drsehgal@ndf.vsnl.net.in.

Received date: April 16, 2018; Accepted date: May 15, 2018; Published date: May 21, 2018

Copyright: $\odot 2018$ Sehgal VN. This is an open-access article distributed under the terms of the Creative Commons Attribution License, which permits unrestricted use, distribution, and reproduction in any medium, provided the original author and source are credited.

Abstract
Atopic dermatitis is well-known age-related/oriented caption recognized through well-defined clinical features
usually having an onset in infancy invariably marching towards childhood, adolescent adult and elderly (senile)
phases. This particular aspect seems unique, and was succinctly explored through literature, the highlights of which
form the position paper for vivid comprehension of evolving clinical spectrum, which might add up to elevation of
dreaded symtomatology, a part component of the entity. The criteria for intrinsic and extrinsic variant of AD, in
particular, are emphasized.

Keywords: Atopic dermatitis; Intrinsic; Extrinsic

\section{Introduction}

Atopic dermatitis (AD) a well-conceived age-oriented entity, recognizable through wide spectrum clinical connotation [1], is an intriguing subject for walk the talk. $\mathrm{AD}$ overwhelming impact on quality of life as a public health problem is now being perceived because of its increasing global prevalence affecting both children and adults. Its prevalence is $20 \%$ in children and up-to $3 \%$ in adults (Figure 1) [2]. Nomenclature task force of European academy of allergy and clinical immunology (EAACI) after elaborate deliberations had put-up a 'position paper' on atopic dermatitis, wherein a new nomenclature atopic eczema/dermatitis syndrome (AEDS) was proposed to cover up wide ranging clinical manifestations of $\mathrm{AD}$, emphasizing that the condition is no single but has several components in its fold. Accordingly, the adult-onset $\mathrm{AD}$ was divided into intrinsic/nonallergic (non-I.e.-mediated) [3] type of atopic dermatitis (constitutional dermatitis) and extrinsic/allergic (Figure 2) (I.e.associated) [4,5] type, the outline of which are defined in the adjoining table 1. Its etio-pathogenesis is largely elusive [6], and a subject matter of continuing dialogue Currently, the turbulence in the functions of stratum corneum [7-9] the skin barrier (Figure 3), are being incriminated through genetically determined risk factors along-with the immune system dysfunction [10]. The concomitance of atopic dermatitis in immuno-compromised/susceptible genetic and metabolic disorders might re-enforce the preceding observations. The proposed hypothesis seemed to have added new dimensions to the comprehension of it's under currents and perspective studies. Simultaneously, it is worthwhile to retrieve [11] the clinical undertones in childhood phase of $\mathrm{AD}$, facilitating to establish the continuous march of atopic dermatitis from childhood, adult-onset [12-14] and senile/elderly [15], invariably marked by remissions and recurrence, its hallmark. Furthermore, aforementioned observations are scintillating, and might raise expectations of comprehensive management of nonallergic atopic eczema/dermatitis syndrome (AEDS) (Figure 4) [2].

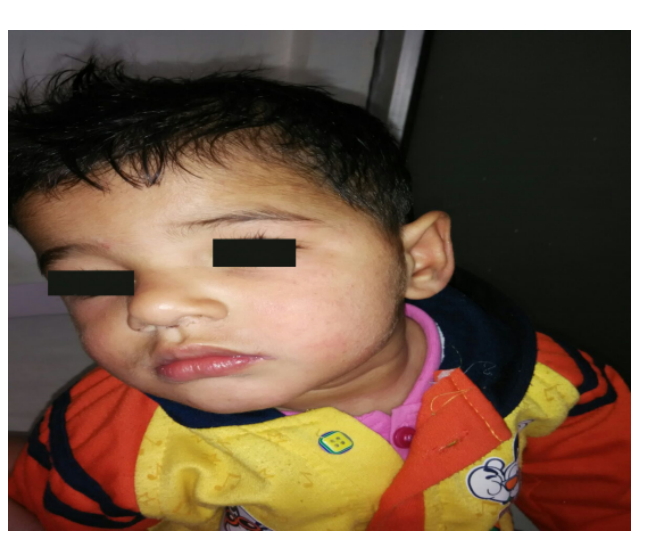

Figure 1: Childhood atopic dermatitis showing non-exuding lichenified lesions affecting the head, neck, wrists, hands, ankles and feet.

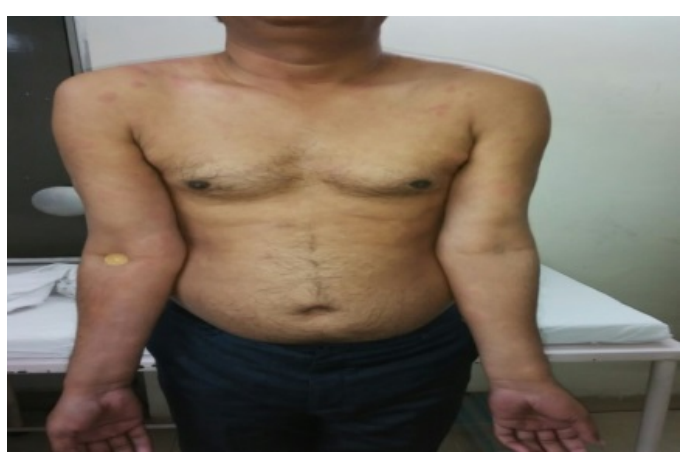

Figure 2: Adult-onset depicting dry, scaly and pigmented skin around the neck and back. 
Page 2 of 3

\begin{tabular}{|c|c|}
\hline \multicolumn{2}{|l|}{ Infantile [16-18] } \\
\hline \multirow[t]{4}{*}{ Less than 2 years } & Typically develops after $2^{\text {nd }}$ month of life \\
\hline & $\begin{array}{l}\text { Edematous papules, papulo-vesicles, and/or } \\
\text { evolving plaques with oozing and crusting over } \\
\text { the cheeks and centro-facial sparing }\end{array}$ \\
\hline & $\begin{array}{l}\text { Face and neck are affected in over } 90 \% \text { of the } \\
\text { patients, in first } 6 \text { months }\end{array}$ \\
\hline & Sparing of diaper area \\
\hline \multicolumn{2}{|l|}{ Childhood [18] } \\
\hline \multirow[t]{4}{*}{2 to 12 years } & Lichenified, less exudative lesions \\
\hline & $\begin{array}{l}\text { Flexural eczema confined to antecubital and } \\
\text { popliteal fossae }\end{array}$ \\
\hline & $\begin{array}{l}\text { Head, especially affecting peri-orificial region, } \\
\text { neck, wrists, hands, ankles and feet }\end{array}$ \\
\hline & Pronounced and widespread xerosis \\
\hline \multirow[t]{4}{*}{ Adolescent Adult [18] } & $\begin{array}{l}\text { More than } 12 \text { and less than } 18 \text { years adult more } \\
\text { than } 18 \text { years }\end{array}$ \\
\hline & $\begin{array}{l}\text { Chronic hand dermatitis, both endogenous and } \\
\text { exogenous components }\end{array}$ \\
\hline & $\begin{array}{l}\text { Facial dermatitis with severe eyelid involvement } \\
\text { in a few }\end{array}$ \\
\hline & $\begin{array}{l}\text { Erythrodermic disease prominent in those with } \\
\text { continuous } A D \text { since childhood }\end{array}$ \\
\hline
\end{tabular}

Senile atopic dermatitis or atopic dermatitis in the elderly $[19,20]$ pattern, types and clinical features: More than 60 years

\begin{tabular}{|c|c|}
\hline \multicolumn{2}{|l|}{ Pattern } \\
\hline \multirow[t]{2}{*}{$\begin{array}{l}\text { Senile /elderly onset [20], } \\
\text { either due to }\end{array}$} & $\begin{array}{l}\text { Recurrence of } A D \text { with a history of classic } \\
\text { childhood } A D \text { or }\end{array}$ \\
\hline & $\begin{array}{l}\text { Continuation of adult-onset } A D \text { marching to } A D \text { in } \\
\text { the elderly }\end{array}$ \\
\hline \multicolumn{2}{|l|}{ Types } \\
\hline \multirow{4}{*}{$\begin{array}{l}\text { Intrinsic atopic dermatitis } \\
1 \text { (iAD) non-allergic atopic } \\
\text { eczema/dermatitis } \\
\text { syndrome (AEDS) } 2\end{array}$} & Normal serum lgE levels $<150-200 \mathrm{kU} / \mathrm{L}$ \\
\hline & Serum specific $\lg E$, none \\
\hline & Association with respiratory diseases, none \\
\hline & $\begin{array}{l}\text { Skin prick testing (SPT) to common aero or food } \\
\text { allergens }\end{array}$ \\
\hline \multirow{4}{*}{$\begin{array}{l}\text { IgE associated allergic } \\
\text { atopic dermatitis, } \\
\text { Extrinsic atopic dermatitis } \\
(\mathrm{eAD})\end{array}$} & Invariably serum lgE level high $>150-200 \mathrm{kU} / \mathrm{L}$ \\
\hline & Serum specific IgE antibodies Positive \\
\hline & Associated allergic rhinitis and/or asthma \\
\hline & SPT Test Positive \\
\hline \multirow{4}{*}{$\begin{array}{l}\text { Environmental factors, } \\
\text { triggers }\end{array}$} & House dust mite \\
\hline & Pollens \\
\hline & Foods \\
\hline & Erythroderma \\
\hline
\end{tabular}

\begin{tabular}{|l|l|}
\hline \multicolumn{2}{|l|}{ Clinical features } \\
\hline $\begin{array}{l}\text { Thickening of the skin, variable scaling arising } \\
\text { secondary to repetitive scratching/rubbing, } \\
\text { lichenification }\end{array}$
\end{tabular}

Table 1: Atopic dermatitis: clinical undertones of age related orientation.

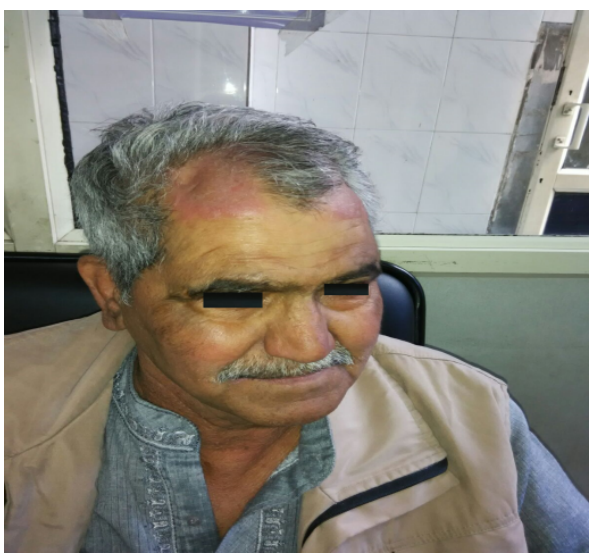

Figure 3: Showing erythematous dry, scaly skin sparing the anticubital fossae.

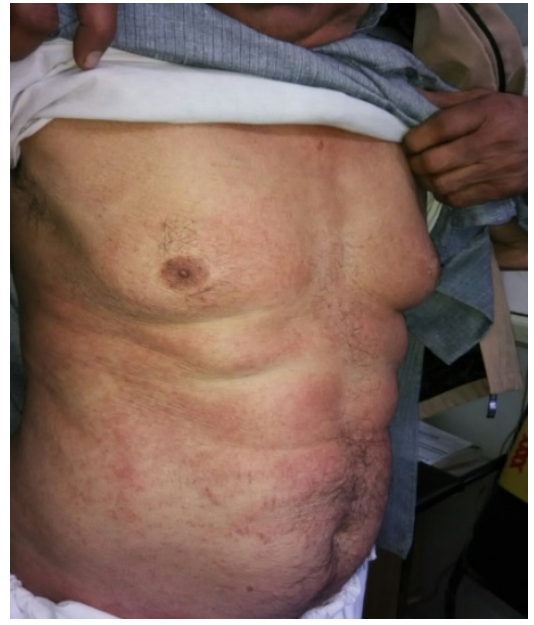

Figure 4: Showing marked xerosis and absence of lichenified flexural lesions.

\section{Discussion}

Atopic dermatitis (AD) has always been focus of walk the talk ever since its initial narrative. Several concerns facets seem to have eluded those chase into unfold its variety of known as well as unknown undertones, an overview of historical [21] vignette may provide a requisite inputs in comprehending an overall position prevailing currently microanatomy of epidermis including stratum corneum, stratum lucidum, stratum granulosum, stratum spinosum and stratum basale. The stratum corneum the formatable skin barrier has been 
moted to play a significant role in its etiopathogenesis through its barriers physiological consituants comprised of loricirin, involucrin, trichohyalin, S 100 proteins and small proline-rich proteins. The stratum corneum has a built-in strength derived from other constiuants layers namely keratins 1 and 10, keratin 2, profilaggrin, transglutaminase-3.

\section{Conclusions}

An exhorted endeavor to evolve status document to decipher the impact of age on course/natural history of atopic dermatitis, is a vital issue for comprehending not only its pattern, type, and also the clinical features, the succinct briefs of which are meticulously scanned, emphasizing the criteria of diagnosis of Intrinsic atopic dermatitis (iAD) non-allergic atopic eczema/dermatitis syndrome (AEDS) alongwith Extrinsic/allergic (IgE-associated) dermatitis.

\section{Learning points}

Atopic dermatitis is an age-related entity extra-ordinary.

Recognized through phases namely infantile, childhood, adolescent, adult and elderly (senile).

Itching/pruritis and/or xerosis is a common ingredient of its symtomatology.

Complimented by lichenification of flexures subsequently also of extenses of the body.

Extrinsic and intrinsic atopic dermatitis are now being envisaged as currently well-conceived and must be documented accordingly, elevated level of immunoglobulin IgE in extrinsic, in particular, is imperative in all phases, especially in senile/elderly [22].

\section{References}

1. Hanifin JM (1982) Atopic dermatitis. J Am Acad Dermatol 6: 1-13.

2. Nutten S (2015) Atopic Dermatitis: Global Epidemiology and Risk Factors Nutrition and Health Department, Nestlé Research Center, Lausanne, Switzerland. Ann Nutr Metab 66: 8-16.

3. Coclici SE, Bozomitu LI, Mîndru DE, Moraru E, Hăncianu M (2016) Atopic Dermatitis-Clinical Epidemiology and Immunological Correlations. Rev Med Chir Soc Med Nat Iasi. 120: 40-47.

4. Wüthrich B, Schmid-Grendelmeier P (2003) The atopic eczema/ dermatitis syndrome. Epidemiology, natural course, and immunology of the IgE-associated ("extrinsic") and the nonallergic ("intrinsic") AEDS. J Investig Allergol Clin Immunol. 13: 1-5.

5. Fölster-Holst R, Pape M, Buss YL, Christophers E, Weichenthal M (2006) Low prevalence of the intrinsic form of atopic dermatitis among adult patients. Allergy 61: 629-632.
6. Sehgal VN, Khurana A, Mendiratta V, Saxena D, Srivastava G, et al.(2015) Atopic dermatitis; etio-pathogenesis, an overview. Indian J Dermatol 60: 327-331.

7. Levin J, Friedlander SF, Del Rosso JQ (2013) Atopic dermatitis and the stratum corneum: part 1: the role of filaggrin in the stratum corneum barrier and atopic skin. J Clin Aesthet Dermatol 6: 16-22.

8. Levin J, Friedlander SF, Del Rosso JQ (2013) Atopic Dermatitis and the Stratum Corneum: Part 2: Other Structural and Functional Characteristics of the Stratum Corneum Barrier in Atopic Skin. J Clin Aesthet Dermatol. 6: 49-54.

9. Levin J, Friedlander SF, Del Rosso JQ (2013) Atopic Dermatitis and the Stratum Corneum: Part 3: The Immune System in Atopic Dermatitis. J Clin Aesthet Dermatol. 6: 37-44.

10. Boguniewicz M, Leung DY (2011) Atopic dermatitis: a disease of altered skin barrier and immune dysregulation. Immunol Rev 242: 233-246.

11. Sehgal VN, Khurana A, Mendiratta V, Saxena D, Srivastava G, et al. (2016) Atopic dermatitis: clinical connotations, especially a focus on concomitant atopic undertones in immuno-compromised/susceptible genetic and metabolic disorders. Indian Journal of Dermatology 61: 241-250.

12. Thappa DM, Malathi M (2013) Is there something called adult onset atopic dermatitis in India?. Indian J Dermatol Venereol Leprol 79: 145-147.

13. Kanwar AJ (2016) Adult-onset atopic dermatitis. Indian J Dermatol 61: 662-663.

14. Kanwar AJ, Narang $\mathrm{T}$ (2013) Adult onset atopic dermatitis: Underrecognized or under-reported? Indian Dermatol Online J 4: 167-171.

15. Dharmage SC, Lowe AJ, Matheson MC, Burgess JA, Allen KJ, et al. (2014) Atopic dermatitis and the atopic march revisited. Allergy 69: 17-27.

16. Tay YK, Khoo BP, Goh CL (1999) The profile of atopic dermatitis in a tertiary dermatology outpatient clinic in Singapore. Int J Dermatol 38: 689-692.

17. Eller E, Kjaer HF, Host A, Andersen KE, Bindslev-Jensen C (2010) Development of atopic dermatitis in the DARC birth cohort. Pediatr Allergy Immunol 21: 307-314.

18. Silverberg NB, Silverberg JI (2017) Atopic dermatitis: Part I. Clin Dermatol. 35: 341-343.

19. Tanei R, Hasegawa Y (2016) Atopic dermatitis in older adults: A viewpoint from geriatric dermatology. Geriatr Gerontol Int.16: 75-86.

20. Katsarou A, Armenaka MC, Zafiriou E, Vakirlis E (2017) Atopic Dermatitis in the Aged. In: Farage M., Miller K., Maibach H. (eds) Textbook of Aging Skin. Berlin, Heidelberg, Springer, Germany.

21. Sehgal VN Senile/elderly atopic dermatitis determination of serum IgE level. (unpublished)

22. Kramer ON, Strom MA, Ladizinski B, Lio PA (2017) The history of atopic dermatitis. Clin Dermatol 35: 344-348. 